\title{
Genotoxicity Assessment in Aqueous and Alcoholic Extracts of Allium sativum, Zingiber Officinale and Trachyspermum ammi
} \author{
Maqbool $^{1}$ and Malik Waseem Abbas ${ }^{3}$ \\ ${ }^{1}$ Institute of Microbiology, University of Agriculture, Pakistan \\ 2Institute of Animal and Dairy Sciences, University of Agriculture, Pakistan \\ 3Livestock and Dairy Development, University of Agriculture, Pakistan
}

Waqar Zaib" ${ }^{1}$, Sajjad Ur Rahman'1, Ahsan Naveed ${ }^{1 *}$, Safdar Imran², Qurratulain Amin ${ }^{1}$, Qamar Majeed ${ }^{1}$, Ayesha

Submission: January 08, 2019; Published: January 24, 2019

*Corresponding author: Ahsan Naveed, Institute of Microbiology, Faculty of Veterinary Science, University of Agriculture, Faisalabad, Pakistan

\begin{abstract}
Purpose: Allium sativum, Trachyspermum, and Zingiber officinale are the plants widely used as spices in edible foods. Although some of these are used in Ethnomedicine as well, their excessive use may result in DNA damage and mutation that come out in the form of cancer. This study was aimed at estimating the genotoxic potential of Allium sativum, Trachyspermum, and Zingiber officinale, their Ethanolic and water extracts were prepared in different concentrations.
\end{abstract}

Method: Lymphocytes from whole blood were separated through centrifugation technique and treated with plant extracts. For the identification of DNA strand breakage and genotoxicity the Comet assay and slide analysis were performed.

Results: The damage in cell membrane disclosed the cytotoxic effect at the highest concentration used while the Genotoxic effect and the DNA damage were poorly expressed.

Conclusion: Comet assay did not reveal a considerable mutagenicity in lymphocytes.

Keyword: Genotoxicity; Allium sativum; Zingiber officinale; Trachyspermum

\section{Introduction}

Any of the substance able to damage DNA and hereditary information is known to be genotoxic. Such substances induce different types of mutations in the genetic material i.e. point mutations, deletions, insertions or changing the chromosomal number and lead towards cancer [1]. The Genotoxic substance induces mutations in the cell via damaging the genomic DNA and leads to cancer [2].

Different plants are extensively used in ethnomedicine because of their therapeutic effects in the cure of certain ailments in underdeveloped regions of the world. However, contrary to their medicinal use, such plants also possess certain chemical mediators which produce toxic effects in the body in the form of chromosomal and DNA damage and lead to pathological and cancerous ailments. Zingiber officinale (Ginger) is extensively used as a major ingredient as well as a therapeutic agent in traditional medicine but their evaluation for systemic safety is still lacking in both human and veterinary side [3]. The genotoxic potential of different plants widely used in ethnomedicine and their ability induce mutations and cytotoxicity has been reported both in vivo and in vitro experiments. Their extensive use results in different types of malignant conditions in humans. This is why before their use as medicinal agent; such plants are required to be checked for their very critical side effects [4].

The mutagenicity of alcoholic extract of ginger and an essential oil has been reported irrespective of activation of the S9 fraction of rat liver. The strain TA-100 and TA-1838 of ginger and shagol are found to be mutagenic respectively. Different genotoxic mediators e.g. 6-gingerol have also been reported in the extract of ginger rhizome [5]. Different in vivo and in vitro tests and assays are used to estimate the genotoxic, cytotoxic, mutagenic as well as carcinogenic effects of different substances. Such assays have different endpoint criteria i.e. DNA damage, chromosomal aberrations, and mutations. These assays are widely employed in detecting carcinogenicity because of an association between genotoxicity and cancer, also the criteria for carcinogenicity assessment assay is not as sensitive as the criteria of genotoxicity 
assessment which is clear from the fact that $50 \%$ of the noncarcinogenic products available in the market are found to have a genotoxic effect. Therefore, for any therapeutic agent to be approved, it should be mandatory to assess it for both genotoxic and carcinogenic effects [6].

It is believed that natural and herbal medicines are safer as compared to synthetic drugs. However, an analytical and toxicological investigation of natural and herbal medicine is not practiced in some underdeveloped countries to check their suitability and safety. They may prove to be very hazardous to human health. Research has proved potential hazardous effects of many plants which are used in the treatment of certain ailments, so instead of producing the therapeutic effect they will result in potential genotoxicity in the body [7].

\section{Material and Methods}

In this study water and ethanolic extracts of three plants Zingiber officinale, A. sativum, and T. ammi were checked for their genotoxic effects. The whole study was conducted at the Institute of Microbiology, University of Agriculture, Faisalabad. Given plants were purchased from the market and washed thoroughly in tap water and distilled water to remove debris. They were cut into small pieces and then air dried at room temperature for crushing and grinding. The aqueous extracts were prepared by mixing the powder in $100 \mathrm{ml}$ sterilized distilled water in a conical flask which was kept at $90{ }^{\circ} \mathrm{C}$ in a water bath for one hour. The solution was then filtered via filter paper five times to obtain the final solution. In order to prepare alcoholic extracts, $100 \mathrm{ml} 70 \%$ ethanol was added in $20 \mathrm{~g}$ of each powder plant material, which was then filtered through cheesecloth to get a final solution [8].

The whole blood samples were collected from goats taking all the hygienic measures in heparin-coated tubes for the separation of lymphocytes. Lysing solution composting of EDTA (in disodium form 0.380 grams, $\mathrm{NH}_{4} \mathrm{Cl}$ Ammonium Chloride 8.050 grams, $\mathrm{NaHCO}_{3}$ Sodium bicarbonate 0.835 grams in $100 \mathrm{ml}$ distilled water for stock is sued to separate the lymphocytes from blood samples. A working solution was prepared by a dilution rate of $10 \mathrm{ml}$ of solution (stock) in $90 \mathrm{ml}$ of the distilled $\mathrm{H}_{2} \mathrm{O}$. Then the procedure of centrifugation, supernatant discarding and suspension of the pellets and then washing the sediment with phosphate buffer saline was done. After final centrifugation, the leukocytes were obtained in the $1 \mathrm{ml}$ tubes for storage and future use.

The single cell suspension technique was used to dissociate the lymphocytes, a final concentration of $2 \times 10^{4} \mathrm{cell} / \mathrm{ml}$ of PBS was adjusted via hemocytometer. The prepared cells were distributed in different wells and treated with different concentration of prepared aqueous and alcoholic plant extracts. The treatment was given with pure plant extracts, double concentration, 2, 3, and 4-fold dilutions of plants extracts in PBS. The control wells were not treated with plants extracts; those were considered as vehicle control to make comparisons. Then these treated cells were mixed with the low melting agarose and incubated at $4{ }^{\circ} \mathrm{C}$. For the comet assay glass slides were firstly coated with the $1 \%$ agarose gel at $100^{\circ} \mathrm{C}$ then these pre-coated slides were dipped into the low melting agarose containing the treated cells at different concentrations of samples. After this, the alkaline lysis is done in the Alkaline buffer $\left(\mathrm{NaCl}_{2} .5 \mathrm{M} 146.1 \mathrm{~g}, \mathrm{Na}_{2}\right.$ EDTA100mM 37.2g, $\mathrm{NaOH} 8 \mathrm{~g}$, Trizma base $10 \mathrm{mM} 1.2 \mathrm{~g}$ in one liter of distilled water) for $20 \mathrm{hrs}$ at $4{ }^{\circ} \mathrm{C}$. The process of electrophoresis was completed on a voltage of $0.6 \mathrm{~V} / \mathrm{cm}$ for a period of 25 minutes by applying a current of about $40 \mathrm{~mA}$ in the Alkaline electrophoreses Buffer ( $\mathrm{NaOH} 300 \mathrm{Mm} 200 \mathrm{~g} / 500 \mathrm{ml}$, EDTA $1 \mathrm{mM} 14.89 / 200 \mathrm{ml}$ at pH 13). Slides removed from the chamber and neutralized by using Tris $0.4 \mathrm{M} \mathrm{48.5/800mld} \mathrm{H}_{2} \mathrm{O}$ at the $\mathrm{pH}$ 7.5. The slides were dipped in the staining solution of Ethidium bromide for $20 \mathrm{~min}$. The slides were subjected to the examination under a microscope. The cells were detected and analyzed by capturing the images of the cells from each slide. These were observed under an optimized digital range of fluorescence. The objects like total intensity (DNA contents), DNA \% in the comet tail, comet's length of the tail and the moment of the tail were analyzed.

\section{Results}

The prepared lymphocytes were treated with a crude extract of Zingiber officinale, Allium sativum and Trachyspermum ammi in different concentrations of water and ethanol. The DNA damage (strand breakage, alkali-labile sites) was observed via comet assay in lymphocytes, which was concluded to be due to the reactivity of genotoxic mediators present in the plant extracts. The cell membrane of the cells was also damaged reflecting the cytotoxic activity of the plant extracts. In comet assay the length of the comet tail indicates DNA damage, greater length means more damage as the Figure 1A \& 1B. DNA content disintegrates near the cell wall and makes shadow this will be low DNA damage as in (Figure 1D).

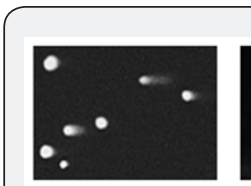

(A)



(B)



(C)
(D)
(A) by Ethanolic extract of Zingiber officinale (ginger).

(B) by extracts of Zingiber officinale (ginger) in water.

(C) Ethanolic extract of Allium sativum (garlic).

(D) Mild damage by Ajwain alcoholic extract.

Figure 1: The damaged DNA on the slide

The DNA damage could be observed either following or without following the cytotoxic effect. Reasonably increasing damage showing the comet tails were observed in the concentration of 0.4 to $0.8 \mathrm{ml}$ of a crude ethanolic extract of Zingiber officinale (ginger) Figure $1 \mathrm{~A}$ while aqueous extracts of Zingiber officinale showed the damage at higher concentrations of 0.6 to $1 \mathrm{ml}$ Figure $1 \mathrm{~B}$. In the case of Allium sativum (garlic), DNA damage was observed in the crude ethanolic extract at the concentration of 0.2 to $0.4 \mathrm{ml}$ Figure $1 \mathrm{C}$ and water extract damage the cell DNA at $0.6 \mathrm{ml}$. The extracts of Trachyspermum ammi (ajwain) reflected minimal DNA damage 
even at higher concentrations of $1 \mathrm{ml}$ in both cases Figure 1D. However, the damage induced in the absence of cytotoxic effect was more critical as compared to the damage accompanied by cytotoxicity $[9,10]$.

\section{Discussion}

Various plants because of their antimicrobial properties are used to cure different infections i.e. diarrhea, dysentery, cough, and asthma. The genotoxicity induced by such plants is used as a basis to treat the ailments. However, their excessive use deteriorates normal cell functioning by damaging DNA. Different dilutions of ginger when tested on root meristem of Allium cepa while taking ethyl methanesulfonate as positive and water as a negative control showed chromosomal aberrations and decreased mitotic index with an increasing concentration of plant extract [11]. The comet assay has been used extensively in detecting genotoxicity both in vivo and in vitro. It has been extensively used to measure DNA by breakage of strands and alkali-labile sites. The in vivo comet assay is applied to all kinds of animal tissues and is able to measure organ-specific toxic effects whereas in vitro comet assay conditions are still to be defined [12]. Certain cytomorphological parameters indicate genotoxicity when it is assessed via simple techniques. All the agrochemical products should be screened for genotoxic effects all over the world because their extensive use of plants results in molecular as well as cellular damage in plants following the increased DNA damage due to oxidative burst. Allium sativum and Allium cepa have been used to treat fertilizers in-plant industry. The chromosomal damage and binucleate cells were observed and the data of both plants were analyzed statistically. The DNA fragmentation and disorientation have also been observed along with a considerable decrease in mitotic abnormality [13]. The cytomorphological and genotoxic assessment of traditionally used plants have disclosed their behavior. Haq et al. [14] used lignin peroxidase for the bioremediation of pulp and paper effluents of mills which decreased the oxygen, lignin, color and phenolic components by 61\%, 95\%, 72\%, and 84\% respectively. Allium cepa and Allium sativum tip cells genotoxicity assay detoxified these effluents $[15,16]$.

\section{Conclusion}

The results obtained in this study encourage more experiments to be conducted to explore the active ingredients which induce mutations and DNA damage. It is also suggested to apply some purification techniques, e.g. HPLC to purify the plant extracts to assess their chemical constituents more accurately. We will also be able to minimize/control the deteriorative effects of such plants by using different techniques. This study investigated the genotoxic potential of these plants' contrary to their medicinal use, indicating that extensive use of these plants either as spices to prepare foods or to cure ailments can create potential health risks.

\section{References}

1. Butterworth BE (1990) Consideration of both genotoxic and nongenotoxic mechanisms in predicting carcinogenic potential. Mutation Res 239(2): 117-132.

2. Nagarathna PKM, Wesley MJ, Reddy PS, Reena K (2013) Review on Genotoxicity, its Molecular Mechanisms and Prevention. Int J Pharm Sci Rev Res 22(1): 236-243.

3. Ali BH, Blunden G, Tanira MO, Nemmar A (2008) Some phytochemical, pharmacological and toxicological properties of ginger (Zingiber officinale Roscoe): a review of recent research. Food Chem Toxicol 46(2): 409-420.

4. Tulay AC (2012) Potential Genotoxic and Cytotoxic Effects of Plant Extracts.

5. Guo X, Chen T (2015) Chapter 7 Progress in Genotoxicity Evaluation of Engineered Nanomaterials Nanomaterials - Toxicity and Risk Assessment.

6. Heidrun EZ, Aubrechta J, Kleinjans C, Ahrb HJ (2009) Application of toxicogenomics to study mechanisms of genotoxicity and carcinogenicity. Toxicol Lett186(1): 36-44.

7. Lee WJ, Kim SC, Lee SJ, Lee J, Park JH (2014) Investigating the Different Mechanisms of Genotoxic and Non-Genotoxic Carcinogens by a Gene Set Analysis. PLoS one 9(1): e86700.

8. Okigbo RN, Ogbonnay UO (2006) Antifungal effects of two tropical plant leaf extracts (Ocimum gratissimum and Aframomum melegueta) on postharvest yam (Dioscorea spp.) rot. African J Biotechnol 5(9).

9. Galloway SM (2000) Cytotoxicity and chromosome aberrations in vitro: Experience in industry and the case for an upper limit of toxicity in the aberration assay. Envir Mol Mutagenesis 35(3): 191-201.

10. Galloway SM, Miller JE, Armstrong MJ (1998) DNA synthesis inhibition as an indirect mechanism of chromosome aberrations: comparison of DNA-reactive and non-DNA-reactive clastogens. Mutation Res 400(12): $169-186$.

11. Ping K, Darah I, Yusuf UK, Yeng C, Sasidharan S (2012) Genotoxicity of Euphorbia hirta: an Allium cepa assay. Molecules 17(7): 7782-7791.

12. Azqueta A, Dusinska M (2015) The use of the comet assay for the evaluation of the genotoxicity of nanomaterials. Frontiers in genetics 6: 239.

13. Verma S, Srivastava A (2017) Cytomorphologic parameters in monitoring cytogenotoxic effects of fertilizer in Allium cepa L. Environ Monit Assess 189(4): 159-165

14. Haq I, Kumar S, Raj A (2017) Genotoxicity assessment of pulp and paper mill effluent before and after bacterial degradation using Allium cepa test. Chemosphere 169: 642-650.

15. Demma J, Engidawork E, Hellman B (2009) Potential genotoxicity of plant extracts used in Ethiopian traditional medicine. J Ethnopharma 122(1): 136-142.

16. Anderson D, TW Yu, Phillips BJ, Schmezer p (1994) The effect of various antioxidants and other modifying agents on oxygen-radicalgenerated DNA damage in human lymphocytes in the COMET assay. Mutat Res 307(1): 261-271. 


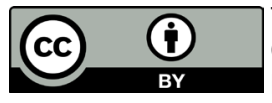

This work is licensed under Creative Commons Attribution 4.0 License DOI: 10.19080/CTBEB.2019.18.555978
Your next submission with Juniper Publishers will reach you the below assets

- Quality Editorial service

- Swift Peer Review

- Reprints availability

- E-prints Service

- Manuscript Podcast for convenient understanding

- Global attainment for your research

- Manuscript accessibility in different formats ( Pdf, E-pub, Full Text, Audio)

- Unceasing customer service

Track the below URL for one-step submission https://juniperpublishers.com/online-submission.php 